\title{
Response of 'Captiva' St. Augustinegrass to Shade and Potassium
}

\author{
Xiaoya Cai ${ }^{1}$ \\ Horticulture Science Department, Texas A\&M University, 419 HFSB, 2133 \\ TAMU, College Station, TX 77843
}

Laurie E. Trenholm

Environmental Horticulture Department, University of Florida, $101 \mathrm{~A}$ Mehrhof Hall, P.O. Box 110670, Gainesville, FL 32611-0675

\author{
Jason Kruse \\ Environmental Horticulture Department, University of Florida, 1511 Fifield \\ Hall, P.O. Box 110670, Gainesville, FL 32611-0670
}

\section{Jerry B. Sartain \\ Soil and Water Science Department, University of Florida, P.O. Box 110510 , Gainesville, FL 32611}

Additional index words. Stenotaphrum secundatum, turfgrass, fertilizer, stress tolerance, total Kjedahl nitrogen

\begin{abstract}
The effects of potassium (K) on stress tolerance of turfgrass have been documented for some environmental stresses but not for shade tolerance. 'Captiva' st. augustinegrass [Stenotaphrum secundatum (Walt.) Kuntze] was evaluated in this research project to determine the effects of $K$ and shade on turf performance. The study was conducted at the University of Florida Envirotron Turfgrass Research Laboratory in Gainesville, FL. Grasses were planted in $15.2-\mathrm{cm}$ plastic pots in a climate-controlled glass house. Two consecutive studies were conducted, the first from 20 May to 24 Oct. 2009 and the second from 18 Jan. to 20 June 2010. Grasses were placed in either full sun or under shade structures covered with woven black shadecloth to provide $30 \%, 50 \%$, or $70 \%$ shade. Potassium was applied as potassium chloride $(\mathrm{KCl})(0-0-62)$ at four rates $(0,0.6$, 1.2 , or $2.4 \mathrm{~g} \cdot \mathrm{m}^{-2}$ ) every 30 days. In both trials, turf visual quality and color scores and dry weight (DW) of shoot and root were lowest at $70 \%$ shade and highest at $30 \%$ shade. Turf visual quality score increased as $K$ rate increased. Leaf length increased and leaf width decreased as shade level increased. Leaf tissue total Kjedahl nitrogen (TKN) and K concentration increased as shade level increased from $0 \%$ to $70 \%$. Thatch DW was greatest at $70 \%$ shade and lowest at $30 \%$ shade. In the first trial, turf treated with a higher $\mathrm{K}$ rate had longer leaf length and greater root $\mathrm{DW}$. Results from this study showed that 'Captiva' could maintain acceptable visual quality at up to $50 \%$ shade and that $\mathrm{K}$ at $2.4 \mathrm{~g} \cdot \mathrm{m}^{-2}$ may help turfgrass grow in a shaded environment by improving turf visual quality score, root growth, and leaf tissue $K$ concentration. Additional field plot research should be conducted to verify these responses.
\end{abstract}

St. augustinegrass [Stenotaphrum secundatum (Walt.) Kuntze] is widely used as a warm-season turfgrass. This is one of the most popular turfgrass species used for home lawns throughout the southern United States. St. augustinegrass has better shade tolerance than many other warm-season grasses (Busey, 2003). There are many commonly produced cultivars of st. augustinegrass, which show different physiological and morphological responses to shade. Peacock and Dudeck (1981) reported that 'Bitter Blue' st. augustinegrass performed best in shade. Trenholm and Nagata (2005) reported best shade tolerance in dwarf cultivars of st. augustinegrass and optimal turf performance

Received for publication 25 Mar. 2011. Accepted for publication 29 June 2011.

${ }^{1}$ To whom reprint requests should be addressed; e-mail xiaoyacai@tamu.edu.
1997; Qian and Engelke, 1998). Potassium has been shown to enhance turfgrass resistance to biotic and environmental stresses (Turner and Hummel, 1992). It can additionally aid in the production of starches, promote root growth, and assist in stomatal regulation (Wallingford, 1980). Potassium was found to be essential for regulatory roles that sustain plant growth and reproduction such as photosynthesis, protein synthesis, ionic balance control, and regulation of plant stomata and water use. Maximum response to $\mathrm{K}$ fertilization was shown to require adequate supplies of other plant nutrients (Callahan and Overton, 1978).

Snyder and Cisar (2000) found that growth of 'Tifgreen' bermudagrass occurred in response to $\mathrm{K}$ application when leaf tissue $\mathrm{K}$ concentration was below $13 \mathrm{~g} \cdot \mathrm{kg}^{-1}$ dry matter, whereas there was no increased leaf tissue $\mathrm{K}$ concentration or growth rate in response to additional $\mathrm{K}$ application when leaf tissue $\mathrm{K}$ concentration was $16 \mathrm{~g} \cdot \mathrm{kg}^{-1}$ dry matter or greater. In a study by Monroe et al. (1969), growth, clipping weight, weight of underground plant parts (root and rhizomes) and tops, vigor score, tiller counts, and blade width were increased by $\mathrm{K}$ application in kentucky bluegrass (Poa pratensis L.). Fitzpatrick and Guillard (2004) noted that kentucky bluegrass showed inconsistent response to $\mathrm{K}$ fertilization. Across varying $\mathrm{N}$ rates and clipping management, $\mathrm{K}$ application had no effect on clipping yields and turf quality although soilextractable $\mathrm{K}$ levels were tested low. There were no yield or quality responses to leaf tissue $\mathrm{K}$ concentration (Fitzpatrick and Guillard, 2004). Trenholm et al. (2000) reported that both hybrid bermudagrass (Cynodon dactylon L. $\times$ C. transvaalensis Burtt-Davy), 'Tifgreen' and 'TifSport', and seashore paspalum (Paspalum vaginatum Swartz.), 'Temple 1', and 'Sea Isle 2000'; and ecotypes HI-1, SIPV-2, and K1 exhibited improved wear tolerance with greater leaf tissue $\mathrm{K}$ concentration. Better visual quality and color scores, shoot density, and wear tolerance correlated with $\mathrm{K}$ application in two paspalum ecotypes (SIPV-2 and K1). However, Johnson et al. (2003) found that there was no significant effect of $\mathrm{K}$ application on creeping bentgrass quality and leaf tissue $\mathrm{K}$ concentration showed a weak correlation with turf quality.

'Captiva' is a new dwarf cultivar of St. Augustingrass that is characterized by dark green, short, narrow leaf blades and reduced vertical leaf extension. 'Captiva' has improved tolerance to southern chinch bug (Blissus insularis Barber) and the plant hopper (Liburnia pseudoseminigra Muir \& Gifford) (Trenholm and Kenworthy, 2009). However, there is little science-based knowledge about responses of 'Captiva' st. augustinegrass to shade and $\mathrm{K}$. This information could provide useful information for management of 'Captiva' under shaded conditions. The objectives of this study were to evaluate the responses of 'Captiva' to shade and $\mathrm{K}$ levels and to determine if $\mathrm{K}$ application could enhance tolerance of 'Captiva' to shaded conditions. 


\section{Materials and Methods}

Two consecutive experiments were conducted in a climate-controlled greenhouse at the Envirotron Turfgrass Research Laboratory at the University of Florida in Gainesville, FL. The first experiment was conducted from 20 May through 24 Oct. 2009 and the second from 18 Jan. through 20 June 2010 . Greenhouse temperature and humidity were monitored using a Hobo data logger (Onset Computer Corporation, Bourne, MA). The average air temperature was 29 and $26^{\circ} \mathrm{C}$ in Trials 1 and 2, respectively, and average humidity was $61 \%$ and $50 \%$ in Trials 1 and 2, respectively.

In May 2009, 'Captiva' st. augustinegrass was established in a $15.2-\mathrm{cm}$ plastic pot. Media of 50\% Fafard 2 mix (Conrad Fafard, Agawam, MA) and 50\% sand (304 T Sand, Interlachen, FL) were used. During establishment, grasses were kept in full sunlight under conditions of optimal irrigation until all pots had established uniform cover, density, and shoot growth. There was no fertilization during establishment, and grasses were mowed to $6.4 \mathrm{~cm}$ before initiation of treatments.

Shade treatments were provided by polyvinyl chloride structures covered with woven black shadecloth to supply shade at $30 \%, 50 \%$, or $70 \%$ of full sunlight. Structures measured $211.8 \mathrm{~cm}$ wide, $173.7 \mathrm{~cm}$ tall, and $211.8 \mathrm{~cm}$ long. There were four $\mathrm{K}$ treatments $(0,0.6$, 1.2 , and $\left.2.4 \mathrm{~g} \cdot \mathrm{m}^{-2}\right)$. Potassium treatments were applied as $\mathrm{KCl}(0-0-62)$ every $30 \mathrm{~d}$ throughout each study period. Shade and $\mathrm{K}$ treatments were initiated on 18 June 2009 in Trial 1 and on 15 Feb. 2010 in Trial 2.

Grasses were mowed at $6.4 \mathrm{~cm}$ by hand monthly throughout each experiment. Nitrogen was applied to all pots at $5.0 \mathrm{~g} \cdot \mathrm{m}^{-2}$ as quickrelease urea (46-0-0) every $60 \mathrm{~d}$. The pots were rotated weekly within shade structures to reduce variability. In the first trial during the summer months, irrigation was applied five times a week at $200 \mathrm{~mL}$ water each time to four shade levels. In the second trial during the winter months, irrigation was applied three times a week at $200 \mathrm{~mL}$ water each time to treatments at $0 \%$ and $30 \%$ shade and $100 \mathrm{~mL}$ water each time to those at $50 \%$ and $70 \%$ shade. The changes in irrigation regime were the result of the reduced light and transpiration in winter and shade conditions. As a result of drought stress of turfgrass at $0 \%$ shade in Trial 1 , irrigation was applied five times a week at $400 \mathrm{~mL}$ water with each application.

During the treatment period, turf was visually rated twice a month for turf quality, color, and density. Turf quality was based on turf vigor, color uniformity, and lack of disease and weed infestations. Visual score was ranked from 1 to 9 with 1 equaling brown, poor turf and 9 representing optimal green grass. A score of 6 was considered a minimum value for acceptable turf quality. Shoot growth was measured once a month by mowing each pot at $6.4 \mathrm{~cm}$ with scissors and collecting all clippings. At the termination of each study, leaves were measured for length from the base of the blade to the apex. Leaf width was also measured. Shoots and roots were separated and dried for $96 \mathrm{~h}$ at $65^{\circ} \mathrm{C}$. Thatch was separated from green living tissue by hand selection of aboveground dead tissues and organic debris and dried for $96 \mathrm{~h}$ at $65{ }^{\circ} \mathrm{C}$. Dried samples were weighed.

The clipped leaves were sampled once a month for TKN (Kjeldahl, 1883) and $\mathrm{K}$ concentration. Tissue samples were dried for $96 \mathrm{~h}$ at $65^{\circ} \mathrm{C}$, ground in a Cyclone Sample Mill (UDY Corporation, Fort Collins, CO), and analyzed for TKN and $\mathrm{K}$ concentration in the Analytical Research Laboratory at the University of Florida.

The experimental design was a nested design with four replications. Potassium treatments were randomized within each shade level for a total of 64 experimental units. Data were analyzed with the SAS analytical program (SAS Institute, 2009) to determine treatment differences at the 0.05 level of significance and means were separated with the WallerDuncan $k$-ratio $t$ test. There were numerous significant interactions between the first and second trials, so data were presented separately by trial.

\section{Results and Discussion}

Turf visual ratings. In Trial 1, turf visual quality score differed as a result of the interaction between shade and $\mathrm{K}$ rate (Table 1 ).
Turf visual quality score increased as $\mathrm{K}$ increased from 0 to $2.4 \mathrm{~g} \cdot \mathrm{m}^{-2}$ at $0 \%$ and $70 \%$ shade, indicating that $\mathrm{K}$ may increase quality in both sun and shade. Turf visual quality score did not differ as a result of $\mathrm{K}$ at $30 \%$ and $50 \%$ shade (Table 2 ). Turf visual color score differed in response to shade with no differences resulting from $\mathrm{K}$ rate or the interaction between shade and $\mathrm{K}$ rate (Table $1)$. The highest turf visual color score was obtained at $30 \%$ shade and lowest score at $70 \%$ shade (Table 3). At $0 \%$ and $70 \%$ shade, turf visual quality score increased as $\mathrm{K}$ level increased with no differences resulting from $\mathrm{K}$ at $30 \%$ or $50 \%$ shade. Averaged over K levels, turf visual quality and color were above acceptable scores at all shade levels in both trials (Table 3). This is similar to results reported by Trenholm and Nagata (2005) for quality and color in dwarf st. augustinegrass, 'Seville', and dwarf experimental line 1997-6 under the same shade treatments. The dwarf cultivars had higher turf quality and color scores than 'Floratam' at the highest shade level. As a result of drought stress that occurred in the $0 \%$ shade treatment, the grasses had reduced visual quality score and shoot density compared with the other shade treatment levels. In Trial

Table 2. Turf visual quality score and leaf tissue total Kjehdahl nitrogen (TKN) in 'Captiva' st. augustinegrass [Stenotaphrum secundatum (Walt.) Kuntze] in response to potassium (K) rate under each shade level when averaged over the trial period in a greenhouse experiment in Trial 1.

\begin{tabular}{lcc}
\hline $\mathrm{K}\left(\mathrm{g} \cdot \mathrm{m}^{-2}\right)$ & Quality $^{\mathrm{z}}$ & Tissue TKN $\left(\mathrm{g} \cdot \mathrm{kg}^{-1}\right)$ \\
\hline \multicolumn{3}{c}{ Shade $=0$} \\
0 & $5.9 \mathrm{c}^{\mathrm{y}}$ & $10.5 \mathrm{~b}$ \\
0.6 & $5.9 \mathrm{c}$ & $12.1 \mathrm{a}$ \\
1.2 & $6.4 \mathrm{~b}$ & $11.8 \mathrm{a}$ \\
2.4 & $6.9 \mathrm{a}$ & $11.8 \mathrm{a}$ \\
$P$ & $<0.0001$ & 0.01
\end{tabular}

Table 1. Analysis of variance for responses of 'Captiva' st. augustinegrass [Stenotaphrum secundatum (Walt.) Kuntze] to shade (S) and potassium (K) in two consecutive greenhouse trials at University of Florida Envirotron Turfgrass Research Laboratory in Gainesville, FL. ${ }^{z}$

\begin{tabular}{|c|c|c|c|c|c|c|c|c|c|}
\hline & Quality & Color & $\begin{array}{c}\text { Shoot DW } \\
\left(\mathrm{g} \cdot \mathrm{m}^{-2}\right)\end{array}$ & $\begin{array}{c}\text { Leaf } \\
\text { length } \\
(\mathrm{mm})\end{array}$ & $\begin{array}{l}\text { Leaf } \\
\text { width } \\
(\mathrm{mm})\end{array}$ & $\begin{array}{c}\text { Root } \\
\text { DW (g) }\end{array}$ & $\begin{array}{c}\text { Thatch } \\
\text { (g) }\end{array}$ & $\begin{array}{l}\text { Tissue TKN } \\
\left(\mathrm{g} \cdot \mathrm{kg}^{-1}\right)\end{array}$ & $\begin{array}{c}\text { Tissue K } \\
\left(\mathrm{g} \cdot \mathrm{kg}^{-1}\right)\end{array}$ \\
\hline \multicolumn{10}{|c|}{ Trial 1} \\
\hline Shade (S) & 0.0001 & 0.0001 & 0.0001 & 0.0001 & 0.0001 & 0.0001 & 0.0001 & 0.0001 & 0.0001 \\
\hline Potassium (K) & 0.0001 & $\mathrm{NS}^{\mathrm{y}}$ & NS & 0.013 & NS & 0.05 & NS & NS & 0.03 \\
\hline $\mathrm{S} \times \mathrm{K}$ & 0.0001 & NS & NS & NS & NS & NS & NS & 0.01 & NS \\
\hline \multicolumn{10}{|c|}{ Trial 2} \\
\hline Shade (S) & 0.0001 & 0.0001 & 0.0001 & 0.0001 & 0.0001 & 0.0001 & 0.0001 & 0.0001 & 0.0001 \\
\hline Potassium (K) & 0.0001 & NS & NS & NS & NS & NS & NS & NS & 0.02 \\
\hline $\mathrm{S} \times \mathrm{K}$ & NS & NS & NS & NS & NS & NS & NS & NS & NS \\
\hline
\end{tabular}

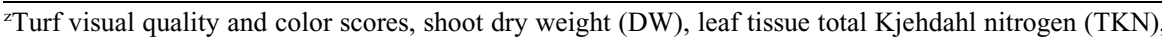
and $\mathrm{K}$ concentration were averaged over each trial period. Leaf length, leaf width, and root dry weight measurements were taken at the termination of each trial.

${ }_{\mathrm{NS}}=$ non-significant at $P=0.05$.

$\mathrm{DW}=$ dry weight.

$\begin{array}{lll} & \text { Shade }=30 \% & \\ 0 & 6.9 & 14.0 \mathrm{a} \\ 0.6 & 6.9 & 13.2 \mathrm{ab} \\ 1.2 & 7.0 & 13.3 \mathrm{ab} \\ 2.4 & 7.0 & 12.6 \mathrm{~b} \\ P & \text { NS }^{\mathrm{x}} & 0.05 \\ & & \\ & \text { Shade }=50 \% & \\ 0 & 6.9 & 14.5 \\ 0.6 & 6.9 & 14.8 \\ 1.2 & 7.0 & 14.8 \\ 2.4 & 7.0 & 14.0 \\ P & \mathrm{NS} & \mathrm{NS} \\ & & \\ & \text { Shade }=70 \% & 16.3 \mathrm{~b} \\ 0 & 5.8 \mathrm{c} & 16.5 \mathrm{~b} \\ 0.6 & 5.8 \mathrm{c} & 17.6 \mathrm{ab} \\ 1.2 & 6.1 \mathrm{~b} & 18.2 \mathrm{a} \\ 2.4 & 6.6 \mathrm{a} & 0.05 \\ P & <0.0001 & \end{array}$

${ }^{\mathrm{z}}$ Turf quality was based on a scale of 1 to 9 , where $1=$ dead, brown turf and $9=$ optimal healthy, green turf. A score of 6 was considered minimally acceptable for a home lawn.

${ }^{y}$ Values in a column within shade treatment followed by different letters differ significantly at $P=0.05$.

${ }^{\mathrm{x}} \mathrm{NS}=$ Non-significant at $P=0.05$. 
2 , turf visual quality score differed in response to main effects of shade and $\mathrm{K}$ (Table 1 ). Best visual quality score was at $30 \%$ shade and at the two highest $\mathrm{K}$ rates (Tables 3 and 4). Turf visual color score differed as a result of shade with the highest visual color score at $30 \%$ shade and lowest scores at $70 \%$ shade (Table 3). Similar responses to shade for turf visual quality score had been reported (Barrios et al., 1986; Qian and Engelke, 2000; Trenholm and Nagata, 2005). Turf visual quality was varied in response to $\mathrm{K}$ rate. Snyder and Cisar (2000) reported that increasing $\mathrm{K}$ fertilizer beyond a $\mathrm{K}: \mathrm{N}$ fertilization ratio of $1: 2$ had no effect on turf quality in 'Tifgreen' bermudagrass. Turf visual quality score increased in 'FloraDwarf' and 'Tifdwarf' hybrid bermudagrass in response to $\mathrm{K}$ rate in a greenhouse study (Trenholm et al., 1998), whereas Johnson et al. (2003) reported no quality response to K rate in 'Providence' creeping bentgrass.

Potassium has been shown to increase tolerance to abiotic stresses in turf, including wear tolerance (Shearman and Beard, 1975; Trenholm et al., 2000) and cold tolerance (Adams and Twersky, 1960; Juska and Murray, 1974), although Miller and Dickens (1996) reported no benefit to high rates of $\mathrm{K}$ for enhancing cold tolerance in 'Tifdwarf' and
'Tifway' bermudagrass. Increased turf quality under shaded conditions reported here may be attributable to increased rooting capacity as seen in Trial 1, possible enhanced plant water relations associated with higher $\mathrm{K}$ concentration, or a combination of factors favorably influencing physiological functioning under shaded conditions.

Shoot growth. In both trials, shoot DW of 'Captiva' differed in response to shade with the highest DW at 30\% shade and lowest at $70 \%$ shade (Tables 1 and 3 ). This is similar to results reported by Trenholm and Nagata (2005) for st. augustinegrass, 'Bitter Blue', 'Floratam', 'Palmetto', 'Seville', and the experimental line 1997-6 and Barrios et al. (1986), who reported that clipping yield of 'Floratam' and 'Floratine' generally decreased with increasing shade. Allard and Nelson (1991) reported that dry matter production of tall fescue was reduced at low irradiance ( $70 \%$ shade) as a result of fewer tillers per plant with no shoot growth response to $\mathrm{K}$ rate. Fitzpatrick and Guillard (2004) also reported no shoot growth in response to $\mathrm{K}$ rate in kentucky bluegrass.

Leaf length. In Trial 1, leaf length differed as a result of main effects of shade level and $\mathrm{K}$ rate (Table 1). Length increased $72.2 \%$ as shade increased from $0 \%$ to $70 \%$, and it

Table 3. Turf visual quality and color scores, shoot dry weight (DW), leaf length and width, root dry weight (DW), thatch, leaf tissue total Kjehdahl nitrogen (TKN), and potassium (K) concentration in response to shade in 'Captiva' st. augustinegrass [Stenotaphrum secundatum (Walt.) Kuntze] in two consecutive greenhouse trials.

\begin{tabular}{|c|c|c|c|c|c|c|c|c|c|}
\hline Shade (S) & Quality $^{z}$ & Color & $\begin{array}{l}\text { Shoot } \\
\text { DW } \\
\left(\mathrm{g} \cdot \mathrm{m}^{-2}\right)\end{array}$ & $\begin{array}{l}\text { Leaf } \\
\text { length } \\
(\mathrm{mm})\end{array}$ & $\begin{array}{l}\text { Leaf } \\
\text { width } \\
(\mathrm{mm})\end{array}$ & $\begin{array}{l}\text { Root } \\
\text { DW } \\
\text { (g) }\end{array}$ & $\begin{array}{c}\text { Thatch } \\
\text { (g) }\end{array}$ & $\begin{array}{c}\text { Tissue } \\
\text { TKN } \\
\left(\mathrm{g} \cdot \mathrm{kg}^{-1}\right)\end{array}$ & $\begin{array}{c}\text { Tissue K } \\
\left(\mathrm{g} \cdot \mathrm{kg}^{-1}\right)\end{array}$ \\
\hline \multicolumn{10}{|c|}{ Trial 1} \\
\hline 0 & $6.16 \mathrm{c}^{\mathrm{y}}$ & $6.6 \mathrm{~b}$ & $1.2 \mathrm{c}$ & $131.4 \mathrm{~d}$ & $7.1 \mathrm{a}$ & $0.6 \mathrm{~b}$ & $1.6 \mathrm{~b}$ & $11.5 \mathrm{c}$ & $10.2 \mathrm{~d}$ \\
\hline $30 \%$ & $7.03 \mathrm{a}$ & $7.4 \mathrm{a}$ & $1.7 \mathrm{a}$ & $175.1 \mathrm{c}$ & $6.9 \mathrm{~b}$ & $0.7 \mathrm{a}$ & $0.9 \mathrm{~d}$ & $13.3 \mathrm{~b}$ & $12.7 \mathrm{c}$ \\
\hline $50 \%$ & $6.96 \mathrm{~b}$ & $7.3 \mathrm{a}$ & $1.5 \mathrm{~b}$ & $197.6 \mathrm{~b}$ & $6.3 \mathrm{c}$ & $0.3 \mathrm{c}$ & $1.1 \mathrm{c}$ & $14.5 \mathrm{~b}$ & $14.8 \mathrm{~b}$ \\
\hline $70 \%$ & $6.02 \mathrm{~d}$ & $6.1 \mathrm{c}$ & $0.8 \mathrm{~d}$ & $226.3 \mathrm{a}$ & $5.3 \mathrm{~d}$ & $0.1 \mathrm{~d}$ & $2.1 \mathrm{a}$ & $17.1 \mathrm{a}$ & $18.1 \mathrm{a}$ \\
\hline \multicolumn{10}{|c|}{ Trial 2} \\
\hline 0 & $7.5 \mathrm{~b}$ & $7.3 \mathrm{c}$ & $1.8 \mathrm{a}$ & $117.0 \mathrm{~d}$ & $7.1 \mathrm{a}$ & $2.3 \mathrm{a}$ & $0.7 \mathrm{c}$ & $17.5 \mathrm{c}$ & $14.4 \mathrm{~d}$ \\
\hline $30 \%$ & $7.9 \mathrm{a}$ & $7.7 \mathrm{a}$ & $1.8 \mathrm{a}$ & $159.0 \mathrm{c}$ & $6.6 \mathrm{~b}$ & $1.9 \mathrm{~b}$ & $0.5 \mathrm{~d}$ & $19.2 \mathrm{c}$ & $18.4 \mathrm{c}$ \\
\hline $50 \%$ & $7.4 \mathrm{c}$ & $7.4 \mathrm{~b}$ & $1.5 \mathrm{~b}$ & $187.1 \mathrm{~b}$ & $6.3 \mathrm{c}$ & $1.5 \mathrm{c}$ & $0.8 \mathrm{~b}$ & $21.1 \mathrm{~b}$ & $20.8 \mathrm{~b}$ \\
\hline $70 \%$ & $6.3 \mathrm{~d}$ & $6.1 \mathrm{~d}$ & $1.0 \mathrm{c}$ & $229.6 \mathrm{a}$ & $5.6 \mathrm{~d}$ & $1.2 \mathrm{~d}$ & $1.8 \mathrm{a}$ & $24.1 \mathrm{a}$ & $25.4 \mathrm{a}$ \\
\hline
\end{tabular}

${ }^{\mathrm{z}}$ Turf quality was based on a scale of 1 to 9 , where $1=$ dead, brown turf and $9=$ optimal healthy, green turf. A score of 6 was considered minimally acceptable for a home lawn.

${ }^{y}$ Values in a column within a trial followed by different letters differ significantly at $P=0.05$.

Table 4. Turf visual quality score, leaf length, root dry weight (DW), and leaf tissue potassium (K) concentration in response to $\mathrm{K}$ rate in 'Captiva' st. augustinegrass [Stenotaphrum secundatum (Walt.) Kuntze] in two consecutive greenhouse trials.

\begin{tabular}{lcccc}
\hline $\mathrm{K}\left(\mathrm{g} \cdot \mathrm{m}^{-2}\right)$ & Quality $^{\mathrm{z}}$ & $\begin{array}{c}\text { Leaf length } \\
(\mathrm{mm})\end{array}$ & Root DW $(\mathrm{g})$ & $\begin{array}{c}\text { Tissue K } \\
\left(\mathrm{g} \cdot \mathrm{kg}^{-1}\right)\end{array}$ \\
\hline 0 & & Trial 1 & & \\
0.6 & $6.57 \mathrm{c}^{\mathrm{y}}$ & $174.1 \mathrm{c}$ & $0.3 \mathrm{c}$ & $13.2 \mathrm{~b}$ \\
1.2 & $6.76 \mathrm{~b}$ & $182.2 \mathrm{~b}$ & $0.4 \mathrm{~b}$ & $13.6 \mathrm{~b}$ \\
2.4 & $6.79 \mathrm{~b}$ & $189.4 \mathrm{a}$ & $0.4 \mathrm{~b}$ & $14.7 \mathrm{a}$ \\
& $6.85 \mathrm{a}$ & $191.2 \mathrm{a}$ & $0.5 \mathrm{a}$ & $14.8 \mathrm{a}$
\end{tabular}

\begin{tabular}{lcccc} 
& \multicolumn{1}{c}{ Trial 2} & \\
0 & $7.1 \mathrm{c}$ & 168.6 & 1.7 & $19.3 \mathrm{~b}$ \\
0.6 & $7.5 \mathrm{~b}$ & 175.7 & 1.7 & $19.3 \mathrm{~b}$ \\
1.2 & $7.6 \mathrm{a}$ & 173.6 & 1.7 & $19.5 \mathrm{~b}$ \\
2.4 & $7.6 \mathrm{a}$ & 174.7 & 1.7 & $20.9 \mathrm{a}$ \\
\hline
\end{tabular}

${ }^{\mathrm{z}}$ Turf quality was based on a scale of 1 to 9 , where $1=$ dead, brown turf and $9=$ optimal healthy, green turf. A score of 6 was considered minimally acceptable for a home lawn.

${ }^{y}$ Values in a column within a trial followed by different letters differ significantly at $P=0.05$. increased $9.8 \%$ as $\mathrm{K}$ rate increased from 0 to $2.4 \mathrm{~g} \cdot \mathrm{m}^{-2}$ (Tables 3 and 4). In Trial 2, leaf length differed only as a result of shade level, increasing $96.2 \%$ as shade level increased from $0 \%$ to $70 \%$ (Tables 1 and 3). Previous research had reported similar leaf length responses to shade (Allard and Nelson, 1991; Dudeck and Peacock, 1992; Peacock and Dudeck, 1981; Trenholm and Nagata, 2005). Allard and Nelson (1991) found that recently developed leaf blades of tall fescue were $54 \%$ to $65 \%$ longer at $70 \%$ shade than at $0 \%$ shade.

Leaf width. In both Trials 1 and 2, leaf width decreased in both trials with increased shade levels (Table 3 ), which had previously been reported in st. augustinegrass (Trenholm and Nagata, 2005), whereas Allard and Nelson (1991) reported no difference in blade width of tall fescue resulting from shade. Monroe et al. (1969) reported that K application increased blade width in kentucky bluegrass.

Root growth. In Trial 1, root DW differed in response to shade and $\mathrm{K}$ rate (Table 1 ) and in response to shade only in Trial 2 (Table 1). Greatest root DW was at $30 \%$ shade in Trial 1 and at $0 \%$ shade in Trial 2. For both trials, it was lowest at $70 \%$ shade. Similarly, Qian and Engelke (2000) found that root mass and number decreased with increasing shade levels in 'Diamond' zoysiagrass (Zoysia japonica Stedu.). Root DW in Trial 1 increased as K rate increased from 0 to $2.4 \mathrm{~g} \cdot \mathrm{m}^{-2}$ (Tables 3 and 4). Juska et al. (1965) found that root growth of kentucky bluegrass was reduced without K application. Similarly, Monroe et al. (1969) reported that K application increased weights of underground plant parts in kentucky bluegrass.

Thatch accumulation. In Trials 1 and 2, thatch accumulation was affected by shade levels with greatest thatch accumulation at $70 \%$ shade and lowest at 30\% shade (Tables 1 and 3). There was no difference in thatch production as a result of $\mathrm{K}$ rate. Previous research had similarly indicated that K application did not affect overall mean of bermudagrass thatch accumulation (Sartain, 1993).

Leaf tissue total Kjeldahl nitrogen concentration. In Trial 1, there was an interaction between shade and $\mathrm{K}$ rate (Table 1). At $0 \%$ shade, turf treated with $0 \mathrm{~g} \cdot \mathrm{m}^{-2} \mathrm{~K}$ rate had the lowest leaf tissue TKN (Table 2; Fig. 1). At $30 \%$ shade, greatest leaf tissue TKN was reached at $0 \mathrm{~g} \cdot \mathrm{m}^{-2} \mathrm{~K}$ rate and the lowest was at $2.4 \mathrm{~g} \cdot \mathrm{m}^{-2} \mathrm{~K}$ rate, which may be the result of nutrient competition between $\mathrm{K}$ and $\mathrm{N}$. At $50 \%$ shade, there was no difference in leaf tissue TKN resulting from $\mathrm{K}$ rate. At $70 \%$ shade, turf had the highest leaf tissue TKN at $2.4 \mathrm{~g} \cdot \mathrm{m}^{-2} \mathrm{~K}$ rate and the lowest at 0 and 0.6 $\mathrm{g} \cdot \mathrm{m}^{-2} \mathrm{~K}$ rates. In Trial 2, leaf tissue TKN differed in response to shade only, increasing as shade increased from $0 \%$ to $70 \%$ (Tables 1 and 3).

Leaf tissue potassium concentration. In Trial 1, leaf tissue $\mathrm{K}$ concentration increased from 10.2 to $18.1 \mathrm{~g} \cdot \mathrm{kg}^{-1}$ as shade increased from $0 \%$ to $70 \%$ (Tables 1 and 3 ). Trenholm and Nagata (2005) reported that leaf tissue K concentration increased from 15.0 to 24.2 $\mathrm{g} \cdot \mathrm{kg}^{-1}$ as shade increased from $0 \%$ to $70 \%$ in 


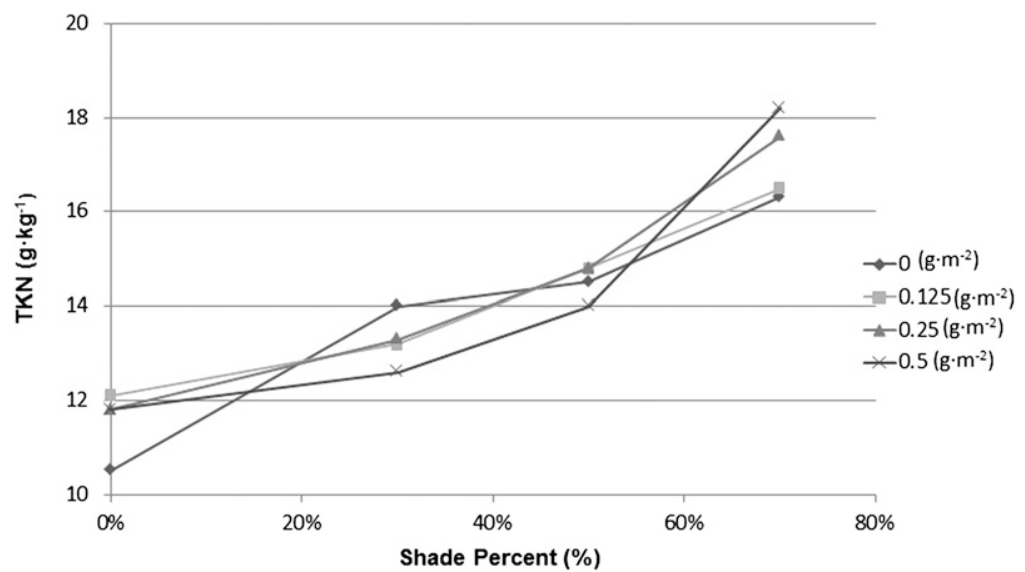

Fig. 1. Interaction between shade level and potassium $(\mathrm{K})$ rate for total Kjeldahl nitrogen (TKN) in 'Captiva' St. Augustine [Stenotaphrum secundatum (Walt.) Kuntze] when averaged over the trial period in a greenhouse experiment in Trial 1.

'Floratam' st. augustinegrass. Increasing leaf tissue $\mathrm{K}$ concentration may indicate that more $\mathrm{K}$ was required to regulate physiological processes such as enzyme activation and stomatal control under the imposed stress conditions. There were differences in leaf tissue $\mathrm{K}$ concentration as a result of $\mathrm{K}$ rate with greater leaf tissue $\mathrm{K}$ concentration at the two highest $\mathrm{K}$ rates (Tables 1 and 4). In Trial 2, leaf tissue $\mathrm{K}$ concentration increased similarly in response to increasing shade and $\mathrm{K}$ levels (Tables 1, 3, and 4). McCrimmon (2004) found that high or low $\mathrm{K}$ rate did not affect leaf tissue $\mathrm{K}$ concentration in 'Raleigh' and 'Palmetto' st. augustinegrass. Sartain (2002) reported that there was no effect of $\mathrm{K}$ application on leaf tissue $\mathrm{K}$ concentration when $\mathrm{K}$ to $\mathrm{N}$ was applied beyond a ratio of 1:2 in 'Tifway' bermudagrass. Snyder and Cisar (2000) found no response in leaf tissue $\mathrm{K}$ concentration to additional $\mathrm{K}$ application, whereas leaf tissue $\mathrm{K}$ level was $16 \mathrm{~g} \cdot \mathrm{kg}^{-1}$ dry matter or greater in 'Tifgreen' bermudagrass. Potassium content in leaf tissue was relative proportional to applied $\mathrm{K}$ rate in kentucky bluegrass (Monroe et al., 1969), whereas Petrovic et al. (2005) found that $\mathrm{K}$ application alone did not increase leaf tissue $\mathrm{K}$ concentration.

\section{Conclusion}

From the results of these two trials, we can conclude that $\mathrm{K}$ may improve turf performance of 'Captiva' under shade. Over all shade levels, turf had best visual quality score at $2.4 \mathrm{~g} \cdot \mathrm{m}^{-2} \mathrm{~K}$ rate, whereas turf at $0 \mathrm{~g} \cdot \mathrm{m}^{-2} \mathrm{~K}$ rate had lower visual quality score. Increased shade resulted in greater thatch accumulation. Turf visual quality score improved with moderate increases in shade. Turf under shade had higher leaf tissue TKN and $\mathrm{K}$ concentration. Additional field research should be conducted to verify these responses in the landscape.

\section{Literature Cited}

Adams, E.W. and M. Twersky. 1960. Effect of soil fertility on winter killing of coastal bermudagrass. Agron. J. 52:325-326.

Allard, G. and C.J. Nelson. 1991. Shade effects on growth of tall fescue: I. Leaf anatomy and dry matter partitioning. Crop Sci. 31:163-167.

Barrios, E.P., F.J. Sundstrom, D. Babcock, and L. Leger. 1986. Quality and yield response of four warm-season lawngrasses to shade conditions. Agron. J. 78:270-273.

Busey, P. 2003. St. augustinegrass, Stenotaphrum secundatum (Walt.) Kuntze, p. 309-330. In: Casler, M.D. and R.R. Duncan (eds.). Biology, breeding, and genetics of turfgrasses. John Wiley \& Sons, Inc., Hoboken, NJ.

Callahan, L.M. and J.R. Overton. 1978. Effects of lawn management practices in a bermudagrass turf. Tenn. Farm Home Sci. 108:3740.

Dudeck, A.E. and C.H. Peacock. 1992. Shade and turfgrass culture. Agron. J. 32:269-284.

Fitzpatrick, J.M. and K. Guillard. 2004. Kentucky bluegrass response to potassium and nitrogen fertilizer. Crop Sci. 44:1721-1728.

Harivandi, M.A. and V.A. Gibeault. 1997. Turfgrass management in shade. Calif. Turfgrass Cult. 47:1-3.

Johnson, P.G., R.T. Koenig, and K.L. Kopp. 2003. Nitrogen, phosphorus, and potassium responses and requirements in calcareous sand greens. Agron. J. 95:697-702.

Juska, F.V., A.A. Hanson, and C.J. Erickson. 1965. Effects of phosphorus and other treatments on the development of red fescue, Merion and common kentucky bluegrass. Agron. J. 57:7578.

Juska, F.V. and J.M. Murray. 1974. Performance of bermudagrass in the transition zone as affected by potassium and nitrogen, p. 149-154. In: Roberts, E.C. (ed.). Proc 2nd Intl. Turfgrass Res. Conf., Blacksburg, VA; 19-21 June 1973. ASA and CSSA, Madison, WI

Kjeldahl, J. 1883. A new method for the determination of nitrogen in organic matter. Z. Anal. Chem. 22:366.

McCrimmon, J.N. 2004. Effects of mowing height, nitrogen rate, and potassium rate on 'Palmetto' and 'Raleigh' st. augustinegrass. J. Plant Nutr. 27:1-13.

Miller, G.L. and R. Dickens. 1996. Potassium fertilization related to cold resistance in bermudagrass. Crop Sci. 36:1290-1295.

Monroe, C.A., G.D. Coorts, and C.R. Skogley. 1969. Effects of nitrogen-potassium levels on the growth and chemical composition of kentucky bluegrass. Agron. J. 61:294-296.

Peacock, C.H. and A.E. Dudeck. 1981. Effects of shade on morphological and physiological parameters of st. augustinegrass cultivars, p. 493-500. In: Sheard, R.W. (ed.). Proc. 4th Intl. Turfgrass Res. Conf.; 19-23 July; Guelph, Ontario, Canada.

Petrovic, A.M., D. Soldat, J. Gruttadaurio, and J. Barlow. 2005. Turfgrass growth and quality related to soil and tissue nutrient content. Intl. Turfgrass Soc. Res. J. 10:989-997.

Qian, Y. and M.C. Engelke. 1998. Growth regulator boosts zoysia's shade tolerance. Golf Course Management. 66:54-57.

Qian, Y.L. and M.C. Engelke. 2000. 'Diamond' zoysiagrass as affected by light intensity. $\mathrm{J}$. Turfgrass Management. 3:1-13.

Sartain, J.B. 1993. Interraltionships among turfgrasses, clipping recycling, thatch, and applied calcium, magnesium and potassium. Agron. J. $85: 40-43$.

Sartain, J.B. 2002. Tifway bermudagrass response to potassium fertilization. Crop Sci. 42:507-512.

SAS Institute. 2009. SAS user's guide: Statistics. Vers. 9.2. SAS Inst., Cary, NC

Shearman, R.C. and J.B. Beard. 1975. Influence of nitrogen and potassium on turfgrass wear tolerance. Agronomy Abstracts. ASA, Madison, WI. p. 101

Snyder, G.H. and J.L. Cisar. 2000. Nitrogen/potassium fertilization ratios for bermudagrass turf. Crop Sci. 40:1719-1723.

Tegg, R.S. and P.A. Lane. 2004. A comparison of the performance and growth of a range of turfgrass species under shade. J. Exp. Agr. 44:353358.

Trenholm, L.E., R.N. Carrow, and R.R. Duncan. 2000. Mechanisms of wear tolerance in seashore paspalum and bermudagrass. Crop Sci. 40:1350-1357.

Trenholm, L.E., A.E. Dudeck, J.B. Sartain, and J.L. Ciscar. 1998. Bermudagrass growth, total nonstructural carbohydrate concentration, and quality as influenced by nitrogen and potassium. Crop Sci. 38:168-174.

Trenholm, L.E. and K. Kenworthy. 2009. 'Captiva' st. augustinegrass. ENH1137, Univ. of Florida Inst. of Food and Agr. Sci., Gainesville, FL. 9 July 2011. <http://edis.ifas.ufl.edu/pdffiles/ EP/EP39800.pdf>.

Trenholm, L.E. and R.T. Nagata. 2005. Shade tolerance of st. augustinegrass cultivars. HortTechnology 15:267-272.

Turner, T.R. and N.W. Hummel. 1992. Nutritional requirements and fertilization, p. 385-439. In: Waddington, D.V., R.N. Carrow, and R.C. Shearman (eds.). Turfgrass. Agron. Monogr. 32. ASA, CSSA, and SSSA, Madison, WI.

Wallingford, W. 1980. Function of potassium in plants, p. 10-27. In: Potassium for Agriculture. Potash and Phosphate Inst., Atlanta, GA.

Wilson, J.R. and K. Hill. 1990. The growth of Paspalum notatum under the shade of a Eucalyptus grandis plantation canopy or in full sun. Trop. Grassl. 24:24-28. 